Review

\title{
New Peptides Isolated from Lyngbya Species: A Review
}

\section{Li Liu and Kathleen S. Rein *}

Department of Chemistry and Biochemistry, Florida International University, Miami, FL 33199, USA;

E-Mail:1liu004@fiu.edu

* Author to whom correspondence should be addressed; E-Mail: reink@fiu.edu;

Tel.: +1-305-348-6682; Fax: +1-305-348-3772.

Received: 13 April 2010; in revised form: 19 May 2010 / Accepted: 3 June 2010 /

Published: 9 June 2010

\begin{abstract}
Cyanobacteria of the genus Lyngbya have proven to be prodigious producers of secondary metabolites. Many of these compounds are bioactive and show potential for therapeutic use. This review covers peptides and hybrid polyketide-non-ribosomal peptides isolated from Lyngbya species. The structures and bioactivities of 50 Lyngbya peptides which were reported since 2007 are presented.
\end{abstract}

Keywords: Lyngbya; cyanobacteria; peptide; secondary metabolites; bioactivity

\section{Introduction}

Cyanobacteria, also called blue-green algae, are ancient aquatic and photosynthetic prokaryotes. The oldest known fossils of cyanobacteria come from Archaean rocks of Western Australia, dated at 3.5 billion years [1]. Over 300 nitrogen-containing secondary metabolites from marine cyanobacteria have been reported in the literature [2]. It is possible that the ability to produce a wide range of defensive secondary metabolites has contributed to the high degree biological adaptation observed for cyanobacteria [3-6]. These secondary metabolites often enable cyanobacteria to compete effectively in a variety of environments, and many have been presented as lead compounds for further drug development. For instance, the synthetic analog cryptophycin 52 (1), which progressed to Phase II clinical trials for the treatment of patients with platinum-resistant ovarian cancer, is based on the cryptophycin 1 (2) which was isolated from terrestrial cyanobacteria [7,8]. Phase II clinical trials of dolastatin 10 failed to show significant anticancer activity. However, in vitro studies of soblidotin (or TZT-1027, auristatin PE) (4) a synthetic analog of dolastatin 10 (3), showed promising results against human colon adenocarcinomas and has progressed to phase II clinical trials $[9,10]$. Synthadotin (or 
ILX-651) (6), derived from dolastatin 15 (5) showed promising results in phase II clinical trials of inoperable, locally advanced or metastatic melanoma $[9,11]$.<smiles>[R]C(C)CNC(=O)[C@H](Cc1ccc(OC)c(Cl)c1)NC(=O)/C=C/C[C@@H](OC(=O)[C@H](CC(C)C)OC(=O)[C@H]1O[C@H]1c1ccccc1)C(C)C</smiles><smiles>CC[C@H](C)[C@H]([C@H](CC(=O)N1CCC[C@H]1[C@H](OC)[C@@H](C)C(=O)N[C@H](Cc1ccccc1)c1nccs1)OC)N(C)C(=O)[C@@H](NC(=O)[C@@H](C(C)C)N(C)C)C(C)C</smiles><smiles>CC[C@H](C)[C@H]([C@H](O)CC(=O)N1CCC[C@H]1[C@H](OC)[C@@H](C)C(=O)NCCc1ccccc1)N(C)C(=O)[C@@H](NC(=O)C(C(C)C)N(C)C)C(C)C</smiles><smiles>COC1=CC(=O)N(C(=O)[C@H](OC(=O)C2CCCN2C(=O)C2CCCN2C(=O)C(C(C)C)N(C)C(=O)[C@@H](NC(=O)C(C(C)C)N(C)C)C(C)C)C(C)C)[C@@H]1Cc1ccccc1</smiles><smiles>CC(C)C(NC(=O)C(C(C)C)N(C)C(=O)[C@@H](C(C)C)N1CCCC1C(=O)N1CCCC1C(=O)NC(C)(C)C)C(C)C</smiles>

Name $\mathrm{R}$ Cryptophycin 52 (1) $\mathrm{Me}$ Cryptophycin $1(2) \quad \mathrm{H}$
Soblidotin (4)

(or TZT-1027, Auristatin PE)

Dolastatin 15 (5)

Synthadotin (6)

(or Tasidotin, ILX-651)

Cyanobacteria of toxicological or pharmacological significance include the genera Anabaena, Oscillatoria, Microcystis, Nodularia, Cylindrospermopsis and Lyngbya. Lyngbya sp. and Microcystis sp. are easily collected and cultured in the laboratory so that the isolation of compounds in the mg range is possible [12]. Lyngbya is a common and accessible genus of cyanobacteria, which is distributed worldwide throughout tropical and subtropical regions. The unbranched filaments of Lyngbya are cylindrical and usually wider than $6 \mu \mathrm{m}$. The straight, slightly wavy, or rarely coiled Lyngbya filaments usually form large, layered, leathery mats of varied thickness, and then form large benthic or surface blooms in freshwater and sea water. There are an increasing number of Lyngbya species which have been found to produce an impressive array of structurally varied compounds with diverse biological activities [4]. To date, the most important species of genus Lyngbya in terms of secondary metabolite production are L. majuscula, L. martensiana, L. aestuarii and L. wollei. Peptides or peptide containing substructures comprise a major group of cyanobacterial secondary metabolites. 
Many of these compounds were reviewed in 2006 [2]. This review covers new peptides reported from Lyngbya species after 2006, with an emphasis on their structures and biological activities. However, conflicting taxonomic identification of cyanobacteria, including the genus Lyngbya, is common [13]. In most instances, the taxonomic identification was made on the basis of morphological features. Less frequently, identification is made on the basis of rRNA gene sequences. Even when sequence data is available, existing databases are often not adequate for definitive identification even at the genus level. The majority of biological activities reported for the compounds fall into two major categories: cytotoxicity or protease inhibition.

\section{Acyclic Peptides}

Six analogs of dragonamide A (7) [14], including carmabin A (8), dragomabin (9) and dragonamide B (10) [15], dragonamides C-D (11-12) [16] and E (13) [17], were isolated from the marine cyanobacteria Lyngbya majuscula and Lyngbya polychroa. This series possesses an 8 or 10-carbon long terminal alkynamide. To the best of our knowledge, carmabin A (8), dragomabin (9), and dragonamide A (7) were the only Lyngbya metabolites showing good antimalarial activity $\left(\mathrm{IC}_{50}=4.3\right.$, 6.0, and 7.7 $\mu \mathrm{M}$, respectively). Dragonamides A (7) and E (13) were also antileishmanial against Leishmania donovani with $\mathrm{IC}_{50}$ values of 6.5 and $5.1 \mu \mathrm{M}$. However, the nonaromatic analog, dragonamide B (10), was inactive against malaria or leishmaniasis. The lack of activity for dragonamide B (10) suggests that an aromatic amino acid at the carboxy terminus is necessary for antiparasitic activity in this series. Carmabin A (8) was more cytotoxic to Vero cells $\left(\mathrm{IC}_{50}=9.8 \mu \mathrm{M}\right)$ than dragomabin (5) $\left(\mathrm{IC}_{50}=182.3 \mu \mathrm{M}\right)$ or dragonamide $\mathrm{A}(7)\left(\mathrm{IC}_{50}=67.8 \mu \mathrm{M}\right)$. Thus, dragomabin (9) possesses the best differential toxicity between parasite and mammalian cells. It appears that the longer and more branched alkynamide chain of carmabin A (8) leads to the increase in cytotoxicity over that of dragomabin (9). Dragonamides C-D (11-12) showed weak activity in cancer cell viability assays, with the $50 \%$ growth inhibition $\left(\mathrm{GI}_{50}\right)$ values of 56 and $59 \mu \mathrm{M}$ against U2OS osteosarcoma cells, 22 and $32 \mu \mathrm{M}$ against HT29 colon adenocarcinoma cells, and 49 and $51 \mu \mathrm{M}$ against IMR-32 neuroblastoma cells, respectively. These data are similar to cytotoxicity data reported for dragonamides A (7) and B (10) against other cell lines. The antiparasitic activity of dragonamides C-D (11-12) was not reported.

Screening of marine cyanobacteria from the Caribbean coast of Panama led to the identification of two antileishmanial lipopeptides, almiramides B-C (15-16) and their non-active analog, almiramide A (14) from Lyngbya majuscula [18]. Compared with the most closely related secondary metabolite dragonamide A (7), almiramides B-C (15-16) with an extra Ala residue, no methyl group on Vall and the opposite configuration of the $\alpha$-carbon of the lipophilic side chain, showed better antileishmanial potencies $\left(\mathrm{IC}_{50}=2.4\right.$, and $1.9 \mu \mathrm{M}$, respectively), but no antimalarial activity up to $13.5 \mu \mathrm{M}$. The lack of antileishmanial activity for almiramide A (14) indicated that an unsaturated terminus on the lipophilic side chain played a critical role for antileishmanial activity in dragonamides and almiramides. Screening of a synthetic library of almiramide analogs with various modifications at the C- or N-terminus afforded several compounds with similar antileishmanial activity but improved selectivity. 
<smiles>[R3]C(C(=O)N(C)C([R2])C(=O)N(C)C([R3])C(=O)N(C)C([R4])C(N)=O)N(C)[GeH2]</smiles>

\begin{tabular}{|c|c|c|c|c|c|}
\hline Name & $\mathbf{R}_{1}$ & $\mathbf{R}_{2}$ & $\mathbf{R}_{\mathbf{3}}$ & $\mathbf{R}_{4}$ & Acyl \\
\hline Dragonamide A (7) & $i$-Pr & $i$-Pr & $i-\operatorname{Pr}$ & $\mathrm{PhCH}_{2-}$ & \\
\hline Carmabin A (8) & $\mathrm{Bn}$ & $\mathrm{Me}$ & $\mathrm{Me}$ & 4-MeO-PhCH${ }_{2-}^{-}$ & \\
\hline Dragomabin (9) & $\mathrm{Bn}$ & $\mathrm{Me}$ & $\mathrm{Me}$ & 4- $\mathrm{MeO}-\mathrm{PhCH}_{2}-$ & \\
\hline Dragonamide B (10) & $i$-Pr & $i-\operatorname{Pr}$ & $i-\operatorname{Pr}$ & $i-\operatorname{Pr}$ & \\
\hline Dragonamide C (11) & $i$-Pr & $i-\operatorname{Pr}$ & $i-\operatorname{Pr}$ & $i-\operatorname{Pr}$ & \\
\hline Dragonamide D (12) & $i$-Pr & $i-\operatorname{Pr}$ & $i-\operatorname{Pr}$ & $i-\operatorname{Pr}$ & \\
\hline Dragonamide E (13) & $i$-Pr & $i$-Pr & $i-\operatorname{Pr}$ & $\mathrm{PhCH}_{2-}$ & \\
\hline
\end{tabular}<smiles>[R]CCCC[C@H](C)C(=O)N(C)[C@H](C(=O)N(C)[C@H](C(=O)N[C@H](C(=O)N(C)[C@@H](C)C(=O)N(C)[C@H](Cc1ccccc1)C(N)=O)C(C)C)C(C)C)C(C)C</smiles>

\begin{tabular}{ll} 
Name & $\mathrm{R}$ \\
\hline Almiramide A (14) & $\mathrm{CH}_{3} \mathrm{CO}-$ \\
Almiramide B (15) & $\mathrm{CH}=\mathrm{C}-$ \\
Almiramide C (16) & $\mathrm{CH}_{2}=\mathrm{CH}-$
\end{tabular}

Efforts toward finding marine cyanobacterial metabolites with antitumor activity led to the isolation of bisebromoamide (17) from a Lyngbya sp. harvested in Okinawa Prefecture [19]. Bisebromoamide (17) is featured by four unusual structural units, the 2-substituted thiazoline-4-methyl-4-carboxylic acid unit fused to a methyl-proline, 2-(1-oxopropyl) pyrrolidine (Opp) residue, $N$-methyl-bromotyrosine and $N$-pivalamide moiety. Prior to the isolation of bisebromoamide (17), the Opp unit in had not been observed in any natural product. Bisebromoamide (17) showed cytotoxicity against HeLa S3 cells $\left(\mathrm{IC}_{50}=0.04 \mu \mathrm{g} / \mathrm{mL}\right.$ ) and a panel of 39 human cancer cell lines (termed JFCR39) (the average $\mathrm{GI}_{50}=40 \mathrm{nM}$ ). At 10 to $0.1 \mu \mathrm{M}$, bisebromoamide (17) selectively inhibited the phosphorylation of ERK (extracellular signal regulated protein kinase) in NRK (normal rat kidney) cells by PDGF (platelet-derived growth factor)-stimulation. However PKB (protein kinase B), PKD (protein kinase 
D), PLC $\gamma 1$ (phospholipase $\mathrm{C} \gamma 1$ ), or S6 ribosomal protein was not affected by bisebromoamide (17) at the same concentration range. Bisebromoamide (17) did not affect tubulin acylation as other tubulin modulators. It is possible that bisebromoamide (17) targets the ERK signal pathway which is activated in various cancers. Therefore, bisebromoamide (17) has potential as a lead for anticancer drugs.

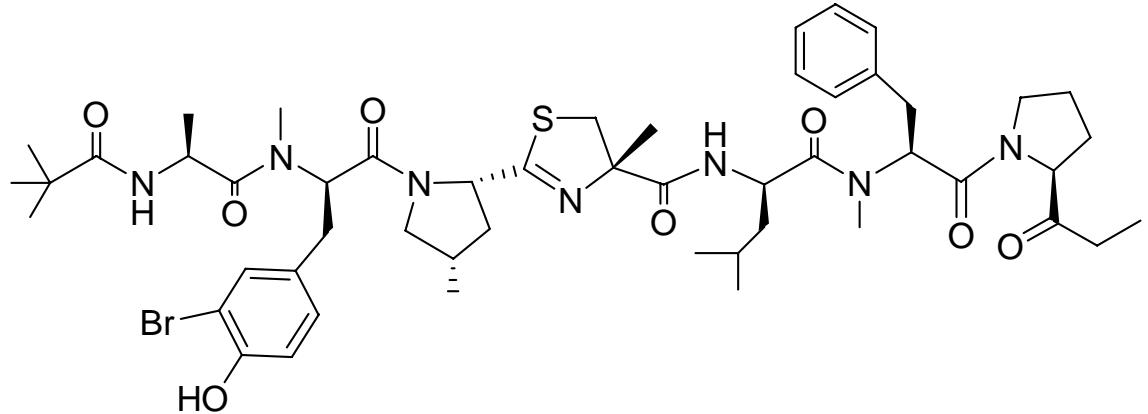

Bisebromoamide (17)

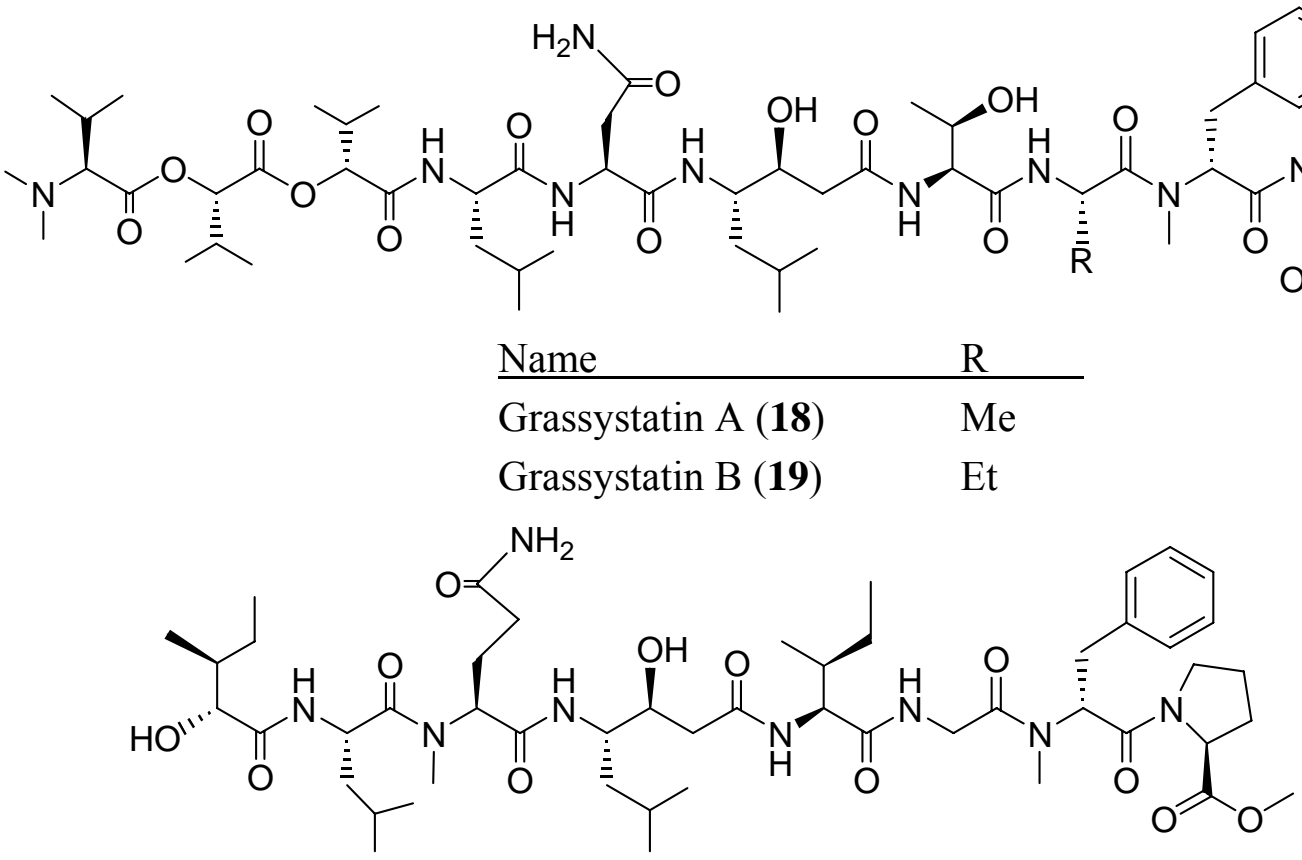

Grassystatin C (20)

Three statine unit ( $\gamma$-amino- $\beta$-hydroxyacid)-containing linear peptides, termed grassystatins $\mathrm{A}-\mathrm{C}$ (18-20), have been isolated from the marine cyanobacteria Lyngbya confervoides collected off Grassy Key in Florida [20]. Grassystatins A and B (18-19) showed similar potency and selectivity against cathepsin $\mathrm{D}$ ( $\mathrm{IC}_{50}$ values of $26.5 \mathrm{nM}$ and $7.27 \mathrm{nM}$, respectively) and $\mathrm{E}$ ( $\mathrm{IC}_{50}$ values of $886 \mathrm{pM}$ and $354 \mathrm{pM}$, respectively). The increased affinity for cathepsin E over cathepsin D may be interpreted by the interaction of the polar asparagine residue in grassystatins A and B (18-19) with glutamine-303 in cathepsin E, which corresponds to the nonpolar residue methionine-307 in cathepsin D. Grassystatin A (15) was observed to reduce antigen presentation by dendritic cells, a process thought to rely on cathepsin E. The truncated peptide analog grassystatin $\mathrm{C}(\mathbf{2 0})$, which consists of two fewer residues than grassystatins A and B (18-19), was less potent against both cathepsins D and E, but still selective for cathepsin E. The selectivity of grassystatins A-C (18-20) for cathepsin E over D (20-38-fold) suggests that these natural products may be useful tools to probe cathepsin E function. In addition, 
grassystatins A-C (18-20) were effective inhibitors of the metalloprotease TACE (tumor necrosis factor $\alpha$-converting enzyme) with $\mathrm{IC}_{50} \mathrm{~s}$ of $1.23 \mu \mathrm{M}, 2.23 \mu \mathrm{M}$ and $28.6 \mu \mathrm{M}$ respectively.

\section{Cyclic Peptides}

An assay-based screening program for new neuroactive compounds from cyanobacteria led to the discovery of alotamide A (21) [21]. Alotamide A (21) is a cyclic depsipeptide featuring three contiguous peptidic residues linked by a polyunsaturated dihydroxyheptaketide which has not been found in any other natural product. Alotamide A (21) displays an unusual calcium influx activation profile in murine cerebrocortical neurons with an $\mathrm{EC}_{50}$ of $4.18 \mu \mathrm{M}$. Although the molecular target and mechanism for the bioactivity of alotamide A (21) is still unclear, alotamide A (21) will attract considerable attention to further study of this new type of cyanobacterial neurotoxin.



Alotamide A (21)

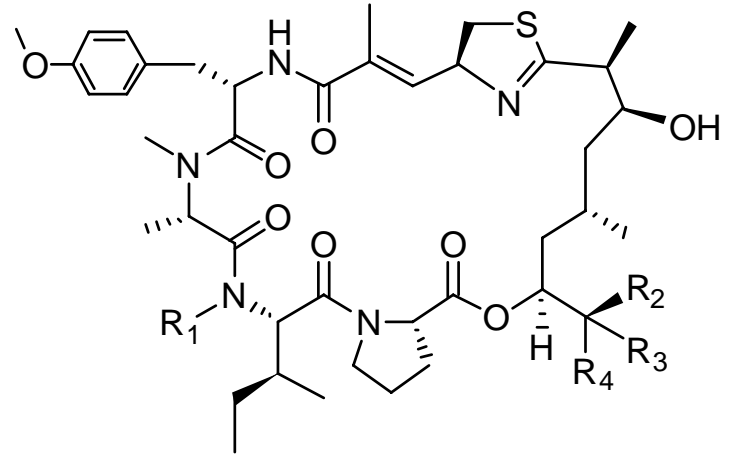

\begin{tabular}{lllll} 
Name & $\mathrm{R}_{1}$ & $\mathrm{R}_{2}$ & $\mathrm{R}_{3}$ & $\mathrm{R}_{4}$ \\
\hline Apratoxin A (22) & $\mathrm{Me}$ & $\mathrm{Me}$ & $\mathrm{Me}$ & $\mathrm{Me}$ \\
Apratoxin B (23) & $\mathrm{H}$ & $\mathrm{Me}$ & $\mathrm{Me}$ & $\mathrm{Me}$ \\
Apratoxin C (24) & $\mathrm{Me}$ & $\mathrm{H}$ & $\mathrm{Me}$ & $\mathrm{Me}$ \\
Apratoxin D (25) & $\mathrm{Me}$ & $\mathrm{Me}$ & $\mathrm{H}$ & $\left(\mathrm{CH}_{3}\right)_{3} \mathrm{CCH}_{2}-$
\end{tabular}

Apratoxin D (25) was isolated from a Papua New Guinea derived strains of the marine cyanobacteria Lyngbya majuscula and Lyngbya sordida [22]. Apratoxin D (25) contains the same macrocycle as apratoxins A-C (22-24) but possesses the unprecedented 3,7-dihydroxy-2,5,8,10,10pentamethylundecanoic acid as the polyketide moiety. Apratoxin D (25) showed potent in vitro cytotoxicity against $\mathrm{H}-460$ human lung cancer cells with an $\mathrm{IC}_{50}$ value of $2.6 \mathrm{nM}$, which is nearly equal in potency to that of apratoxin A (22). The similar cytotoxicity of apratoxin A (22) and apratoxin $\mathrm{D}$ (25) indicates that the cytotoxicity of apratoxins is not strongly impacted by the larger lipopeptide tail. The isolation of apratoxin D (25) from two distinct species of the genus Lyngbya supports the hypothesis of genetic transfer of natural product biosynthetic pathways between marine cyanobacteria [23].

A collection of the marine cyanobacterium Lyngbya bouillonii from Guam afforded the cytotoxic apratoxin E (26) [24]. Apratoxin E (26) displayed stronger cytotoxicity than its closest analog, semisynthetic $E$-dehydroapratoxin A (27) against several cancer cell lines derived from colon, cervix, and bone, ranging from 21 to $72 \mathrm{nM}$, yet is 5- to 15-fold less active than apratoxin A (22). It was speculated that the conformational alteration to apratoxin $\mathrm{E}(\mathbf{2 6})$, which results from the dehydration in the polyketide chain, reduces its activity. 
<smiles>CCC(C)[C@H](C(=O)N1CCCC1C(=O)OC(C[C@@H](C)C/C=C/C1=NC(CCC(=O)N[C@@H](Cc2ccc(OC)cc2)C(=O)N(C)[C@@H](C)C(=O)N(C)C)CS1)C(C)(C)C)C(C)C</smiles>

Apratoxin E (26)



Name

Hantupeptin A (28)

Hantupeptin B (29)

Hantupeptin C (30)<smiles>CCC(C)[C@H](C(=O)N1CCC[C@H]1C(=O)OC(C[C@@H](C)C/C=C(\C)C1=NC(/C=C(\C)C(=O)N[C@@H](Cc2ccc(OC)cc2)C(=O)N(C)[C@@H](C)C(=O)N(C)C)CS1)C(C)(C)C)C(C)(C)C</smiles>

E-dehydroapratoxin A (27)

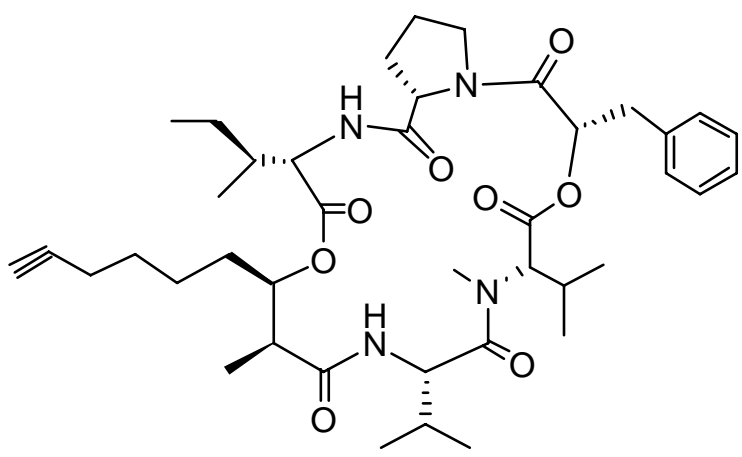

Trungapeptin A (31)

The marine Lyngbya majuscula from Pulau Hantu Besar, Singapore afforded a cyclodepsipeptide, hantupeptins A-C (28-30) [25,26]. Hantupeptin A (28), B (29) and C (30) all showed 100\% brine shrimp mortality at 100 and $10 \mathrm{ppm}$. This was significantly higher than the activity reported for their closest analog trungapeptin A (31), which was only mildly toxic to brine shrimp [27]. Furthermore, in vitro cytotoxicity testing of hantupeptins A (28), B (29) and C (30) against the leukemia cell line MOLT-4, displayed $\mathrm{IC}_{50}$ values of $32 \mathrm{nM}, 0.2 \mu \mathrm{M}$ and $3.0 \mu \mathrm{M}$, respectively and $4.0 \mu \mathrm{M}, 0.5 \mu \mathrm{M}$ and $1.0 \mu \mathrm{M}$, respectively, against the breast cancer cell line MCF-7. In comparison, trungapeptin A (31), was reported to be inactive when tested at $10 \mu \mathrm{g} / \mathrm{mL}$ against $\mathrm{KB}$ or LoVo cells. It may be noteworthy to add that the hantupeptins have the $2 R, 3 S$ absolute configurations while the corresponding stereocenters in trungapeptin are $2 S, 3 R$.

The marine Lyngbya majuscula collected from Palmyra Atoll produced palmyramide A (32), an unusual cyclic depsipeptide composed of three amino acids and three hydroxy acids [28]. The 2,2-dimethyl-3-hydroxyhexanoic acid unit (Dmhha) was also found in guineamide F (33) [29]. Palmyramide A (32) blocked the voltage gated sodium channel in neuro-2a cells $\left(\mathrm{IC}_{50}=17.2 \mu \mathrm{M}\right)$ and showed mild cytotoxicity against $\mathrm{H}-460$ human lung carcinoma cells $\left(\mathrm{IC}_{50}=39.7 \mu \mathrm{M}\right)$. However, the cytotoxicity of guineamide F (33) was not reported. The planar structure of the 2,2-dimethyl-3hydroxy-7-octynoic acid unit-containing dudawalamide A (34) was recently reported [30]. In an interesting correlation to the acyclic dragonamide A (7) and almiramides, it also exhibited antiparasitic activity [31]. 
<smiles>CCC[C@H]1OC(=O)[C@@H](C(C)C)NC(=O)[C@@H](C(C)C)N(C)C(=O)[C@@H]2CCCN2C(=O)[C@H](Cc2ccccc2)OC(=O)[C@H](C)OC(=O)C1(C)C</smiles>

Palmyramide A (32)

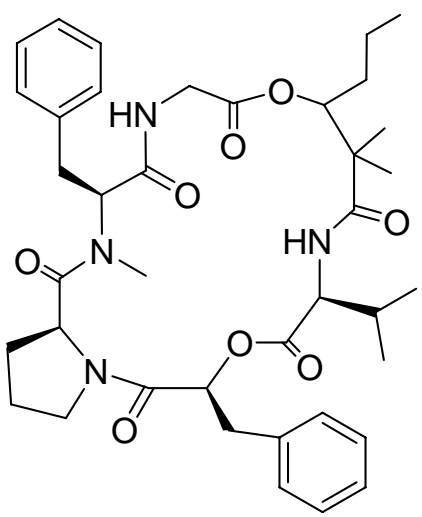

Guineamide F (33)

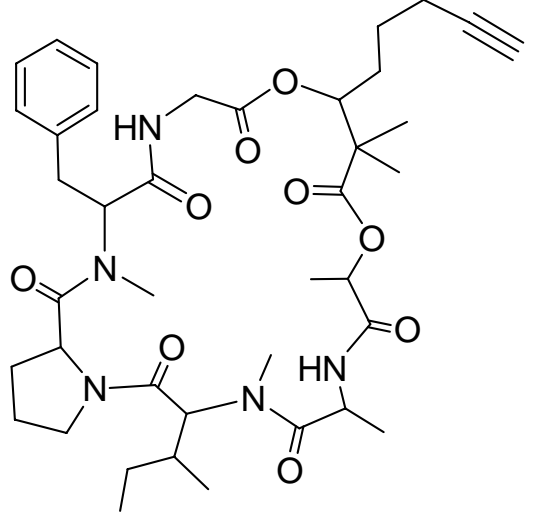

Dudawalamide A (34)

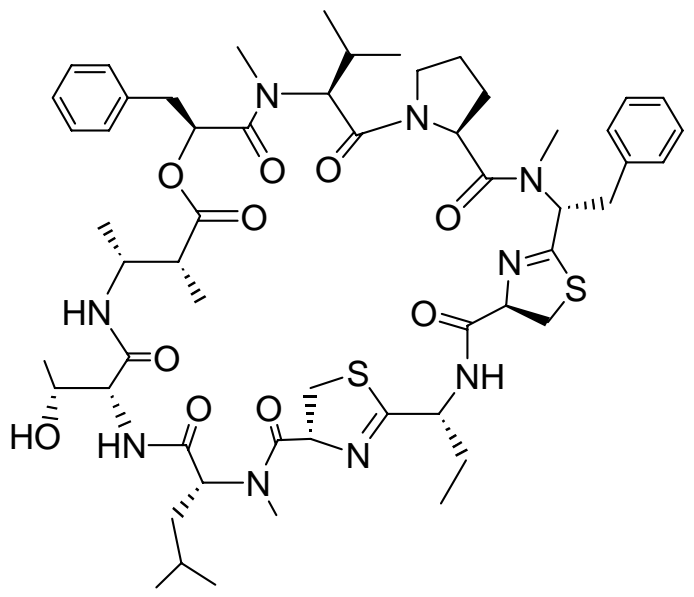

Grassypeptolide (35)



Lissoclinamide 7 (36)

A collection of the cyanobacterium Lyngbya confervoides from the Florida Keys yielded grassypeptolide (35), a macrocyclic depsipeptide with an unusually high $D$-amino acid content, two thiazolines, and one $\beta$-amino acid [32]. Grassypeptolide (35) inhibited four cancer cell lines derived from human osteosarcoma (U2OS), cervical carcinoma (HeLa), colorectal adenocarcinoma (HT29), and neuroblastoma (IMR-32) with $\mathrm{IC}_{50}$ values from 1.0 to $4.2 \mu \mathrm{M}$. These data are within the range of $\mathrm{IC}_{50}$ values reported for lissoclinamide 7 (36) $(53.7 \mathrm{nM}$ to $21.5 \mu \mathrm{M})$, but in different cell lines [33,34]. Lissoclinamide 7 (36), the most cytotoxic of the lissoclinamide series, has two thiazoline rings with the same arrangement and stereoconfiguration as 35. It has been shown that the thiazolines of $\mathbf{3 6}$ are important to its cytotoxic activity [34]. If this is the case, then it is very possible that grassypeptolide (35) and lissoclinamide 7 (36) share a similar mechanism of action.

A cyclodepsipeptide, termed carriebowmide (37) was isolated from the lipophilic EtOAc-MeOHsoluble fraction of Lyngbya polychroa collected from Carrie Bow Cay, Belize [35]. Carriebowmide (37) was also isolated from the same strain of Lyngbya majuscula that produced two depsipeptides, itralamides A and B (53-54) [41]. Carriebowmide (37) contains two rare amino acids, 3-amino-2methylhexanoic acid and methionine sulfoxide. The lipophilic EtOAc-MeOH-soluble fraction from Lyngbya polychroa significantly deterred feeding by a natural assemblage of reef fish. This is presumably due to the presence of carriebowmide (37), however the effectiveness of the purified compound as a feeding deterrent was not determined. 
<smiles>CCC[C@H]1NC(=O)[C@H](C)NC(=O)[C@H](CC(C)C)N(C)C(=O)[C@H](Cc2ccccc2)NC(=O)[C@H](CCS(C)=O)NC(=O)[C@H](Cc2ccccc2)N(C)C(=O)[C@H](CC(C)C)OC1=O</smiles>

Carriebowmide (37)

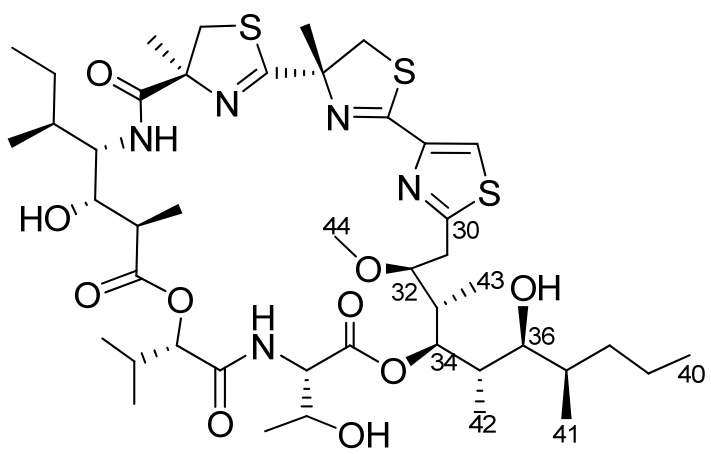

Hoiamide A (38)

A combination of ${ }^{1} \mathrm{H}$ NMR and bioassay-guided screening for neuroactive compounds from cyanobacteria led to the discovery of hoiamide A (38), a bioactive cyclic depsipeptide [36]. The 15 carbon subunit (C30 to $\mathrm{C} 44$ ) appears to be derived from a polyketide pathway. The pattern of oxidation and placement of pendant methyl groups suggests that the eleven-carbon main chain of Dmetua (5,7-dihydroxy-3-methoxy-4,6,8-trimethylundecanoic acid) may arise from the condensation of four propionates and one acetate unit. Hoiamide A (38) acted as a partial agonist at site 2 of the voltage-gate sodium channel $\alpha$ subunit, inhibited batrachotoxin-induced elevation of $\left[\mathrm{Na}^{+}\right]_{\mathrm{I}}$ in a concentration dependant manner, and exhibited modest cytotoxicity to cancer cells.

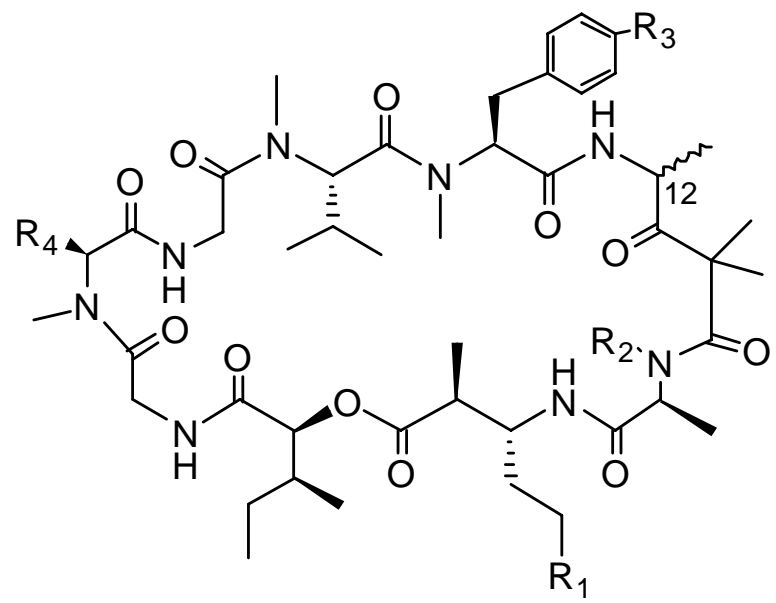

\begin{tabular}{llllll} 
Name & & $\mathbf{R}_{\mathbf{1}}$ & $\mathbf{R}_{\mathbf{2}}$ & $\mathbf{R}_{\mathbf{3}}$ & $\mathbf{R}_{4}$ \\
\hline Desmethoxymajusculamide C $(12 S)$ & $\mathbf{( 3 9 )}$ & $\mathrm{H}$ & $\mathrm{H}$ & $\mathrm{H}$ & $(S)$ sec-Bu \\
Lyngbyastatin 3 $(12 R / S)$ & $\mathbf{( 4 0 )}$ & $\mathrm{Me}$ & $\mathrm{Me}$ & $\mathrm{OMe}$ & $i-\mathrm{Bu}$ \\
Dolastatin 12 $(12 R / S)$ & $(\mathbf{4 1})$ & $\mathrm{H}$ & $\mathrm{Me}$ & $\mathrm{H}$ & $i-\mathrm{Bu}$ \\
Lyngbyastatin 1 $(12 R / S)$ & $(\mathbf{4 2})$ & $\mathrm{H}$ & $\mathrm{Me}$ & $\mathrm{OMe}$ & $i-\mathrm{Bu}$ \\
Majusculamide C $(12 S)$ & $(\mathbf{4 3})$ & $\mathrm{H}$ & $\mathrm{H}$ & $\mathrm{OMe}$ & $(S) s e c-\mathrm{Bu}$
\end{tabular}

Desmethoxymajusculamide C (39) was isolated from Lyngbya majuscula collected in Fiji [37]. The closely related compounds, lyngbyastatin 3 (40), dolastatin 12 (41) and lyngbyastatin 1 (42), were determined to be mixtures of Ibu (4-amino-2,2-dimethyl-3-oxopentanoic acid units) epimers $[R$ (major) and $S$ (minor)] whereas the structurally related majusculamide $\mathrm{C}$ (43) is a single diastereomer with an $S$-Ibu unit. For 40-42, but not 43, significant NMR line broadening was observed. This was 
attributed to two factors: the presence of epimers and differing ratios of cis/trans conformers for individual epimers. Like majusculamide C (43) NMR line broadening was not observed for 39, suggesting the presence of a single Ibu epimer. Desmethoxymajusculamide C (39) and its ring-opened form (generated by breaking the ester bond) demonstrated equivalent efficacy and solid tumor selectivity against four cell lines, including HCT-116, H-460, MDA-MB-435 and Neuro-2A. HCT-116 was the most sensitive cell line, with $\mathrm{IC}_{50}$ values of 20 and $16 \mathrm{nM}$, for 39 and its ring-open analog, respectively. This finding was discordant with the common viewpoint that the cyclic form is the bioactive form of the many peptides.

\section{Cyclic Peptides with One or More Amide or Ester Branches}

Tiglicamides A-C (44-46) were isolated from the Florida marine Lyngbya confervoides along with largamides A-C (47-49) [38,39]. The largamides and tiglicamides differ by only a single amino acid residue in the cyclic core. This single amino acid difference may result from assembly by an NRPS with adenylation domains having unusually relaxed specificity [40] or by a separate biosynthetic pathway. Both the largamides $\mathrm{A}-\mathrm{C}(\mathbf{4 7 - 4 9 )}$ and the tiglicamides $\mathrm{A}-\mathrm{C}(\mathbf{4 4 - 4 6 )}$ are serine protease inhibitors with selectivity for elastase over chymotrypsin and trypsin (Table 1). The carboxylic acid residue has little effect on the elastase inhibitory activity because the semi-synthetic largamide methyl esters 50-52 retained low-micromolar inhibitory activity.

Table 1. Inhibition of serine proteases by peptides from the cyanobacterial genus Lyngbya ( $\left.\mathrm{IC}_{50}, \mu \mathrm{M}\right)$.

\begin{tabular}{lcccc}
\hline \multicolumn{1}{c}{ Name } & Elastase & Chymotrypsin & Trypsin & Reference \\
\hline Tiglicamide A (44) & 2.14 & $>50$ & $>50$ & {$[38]$} \\
Tiglicamide B (45) & 6.99 & $>50$ & $>50$ & {$[38]$} \\
Tiglicamide C (46) & 7.28 & $>50$ & $>50$ & {$[38]$} \\
Largamide A (47) & 1.41 & $>50$ & $>50$ & {$[39]$} \\
Largamide B (48) & 0.53 & $>50$ & $>50$ & {$[39]$} \\
Largamide C (49) & 1.15 & $>50$ & $>50$ & {$[39]$} \\
Pompanopeptin A (55) & 2.4 & & & {$[42]$} \\
Lyngbyastatin 4 (59) & 0.0139 or 0.03 & 4.3 or 0.3 & $>30$ & {$[44,45]$} \\
Lyngbyastatin 5 (60) & 0.0032 & 2.8 & $>30$ & {$[45]$} \\
Lyngbyastatin 6 (61) & 0.0033 & 2.5 & $>30$ & {$[45]$} \\
Lyngbyastatin 8 (62) & 0.0083 or 0.047 & 2.5 & $>30$ & {$[45,46]$} \\
Lyngbyastatin 9 (63) & 0.123 & $/$ & $/$ & {$[46]$} \\
Lyngbyastatin 10 (64) & 0.210 & $/$ & $/$ & {$[46]$} \\
Lyngbyastatin 7 (65) & 0.120 & $/$ & $/$ & {$[46]$} \\
Somamide B (66) & 0.0095 & 4.2 & $>30$ & {$[47]$} \\
Kempopeptin A (67) & 0.32 & 2.6 & $>67$ & {$[48]$} \\
Kempopeptin B (68) & $>67$ & $>67$ & 8.4 & {$[48]$} \\
Scyptolin A (69) & 2.8 & $/$ & $>446$ & {$[50]$} \\
\hline
\end{tabular}




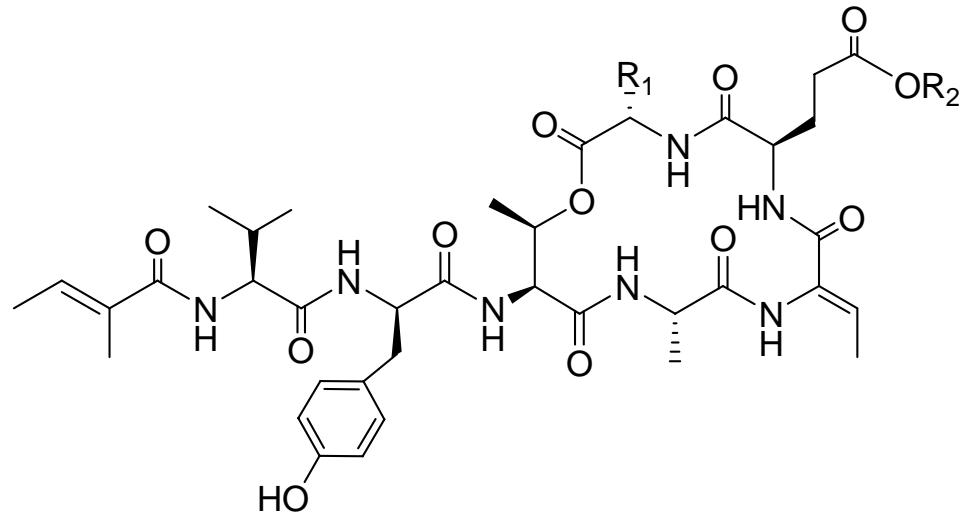

\section{Name}

Tiglicamide A

Tiglicamide B

Tiglicamide $\mathrm{C}$

Largamide A

Largamide B

Largamide C

Largamide A methyl ester

Largamide B methyl ester

Largamide $\mathrm{C}$ methyl ester
$\mathbf{R}_{1} \quad \mathbf{R}_{2}$

4-OH- $\mathrm{PhC}_{2} \mathrm{H}_{4}-\quad \mathrm{H}$

$\mathrm{PhCH}_{2-} \quad \mathrm{H}$

$\mathrm{CH}_{3}-\mathrm{SO}-\mathrm{C}_{2} \mathrm{H}_{4}-\quad \mathrm{H}$

$i$ - $\mathrm{Bu} \quad \mathrm{H}$

4-OH- $-\mathrm{PhC}_{3} \mathrm{H}_{6^{-}} \quad \mathrm{H}$

4-OH- $-\mathrm{PhC}_{4} \mathrm{H}_{8}-\quad \mathrm{H}$

$i$ - $\mathrm{Bu} \quad \mathrm{Me}$

4-OH- $-\mathrm{PhC}_{3} \mathrm{H}_{6-} \quad \mathrm{Me}$

4-OH- $\mathrm{PhC}_{4} \mathrm{H}_{8^{-}} \quad \mathrm{Me}$<smiles>[R1]C1NC(=O)[C@@H](Cc2ccccc2)N(C)C(=O)[C@H](C)N1C</smiles>

\begin{tabular}{lccc} 
Name & $\mathbf{R}_{\mathbf{1}}$ & $\mathbf{R}_{\mathbf{2}}$ & $\underline{\mathbf{R}}_{\mathbf{3}}$ \\
\hline Itralamide A (53) & $\mathrm{Me}$ & $\mathrm{Me}$ & $i$-Pr \\
Itralamide B (54) & $i$-Pr & $i$-Pr & $\mathrm{Me}$
\end{tabular}

An eastern Caribbean collection of Lyngbya majuscula produced two depsipeptides, itralamides A and B (53-54) [41]. Itralamide B (54) displayed significant cytotoxicity in human embryonic kidney (HEK-293) cells $\left(\mathrm{IC}_{50}=6 \pm 1 \mu \mathrm{M}\right)$. The closely related itralamide A (53) had a ten-fold lower potency than itralamide B (54). The difference in the cytotoxicity of itralamides A and B (53-54) demonstrates that biological activities can be dramatically altered by minor modifications of structure.

The investigation of the marine cyanobacterium Lyngbya confervoides collected from the southeastern coast of Florida led to the isolation of 3-amino-6-hydroxy-2-piperidone (Ahp) containing peptolide, pompanopeptin A (55), and a novel cyclic pentapeptide, pompanopeptin B (56) [42]. Pompanopeptin B (56) contains $N$-methyl-2-amino-6-(4'-hydroxyphenyl) hexanoic acid ( $N$-Me-Ahpha) and is structurally related to carboxypeptidase-A inhibitors anabaenopeptins I (57) and $\mathrm{J}$ (58) which were isolated from the cyanobacterium Aphanizomenon flos-aquae. The $L$-Htyr and 
$N$-methyl- $L$-Ahpha, respectively in pompanopeptin B (56) were replaced by $L$-leucine $/ L$-phenylalanine and $N$-methyl- $L$-alanine residues of 57 and 58 [43]. Pompanopeptin A (55) selectively inhibited trypsin over elastase and chymotrypsin, with an $\mathrm{IC}_{50}$ value of $2.4 \mu \mathrm{M}$ (Table 1). The authors concluded that this selectivity is conferred by the arginine residue in the cyclic core. No activity data for $\mathbf{5 6}$ is reported.



Pompanopeptin A (55)



Name Pompanopeptin B (56) 4-OH- $\mathrm{Ph}\left(\mathrm{CH}_{2}\right)_{4}-4-\mathrm{OH}-\mathrm{Ph}\left(\mathrm{CH}_{2}\right)_{2}$ Anabaenopeptin I (57) Anabaenopeptin J (58)
$\mathrm{Me}$ $i-\operatorname{Pr}$

$\mathrm{Me}$

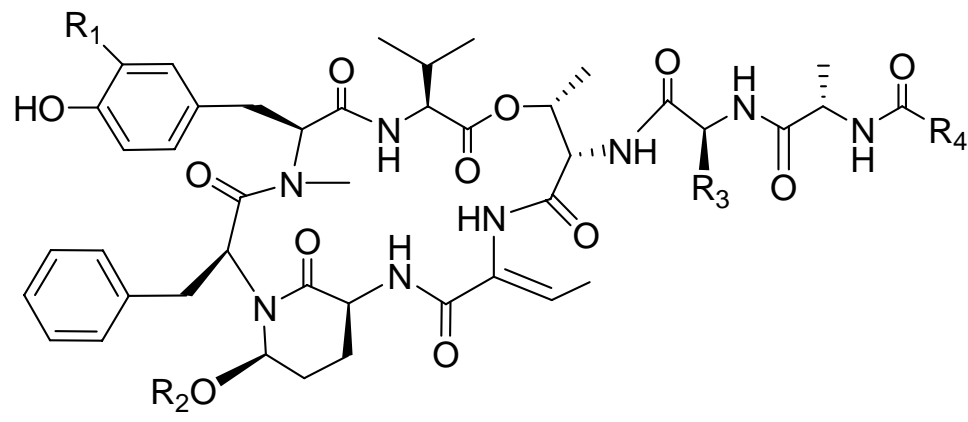

$\mathbf{R}_{1} \quad \mathbf{R}_{2} \quad \mathbf{R}_{3}$ $\mathbf{R}_{4}$

\begin{tabular}{llllll}
\hline Lyngbyastatin 4 & $\mathbf{( 5 9 )}$ & $\mathrm{H}$ & $\mathrm{H}$ & $4-\mathrm{OH}-\mathrm{PhC}_{2} \mathrm{H}_{4}-$ & $\mathrm{HO}_{3} \mathrm{SO}-\mathrm{CH} 2-\mathrm{CH}(\mathrm{OH})-$ \\
Lyngbyastatin 5 & $\mathbf{( 6 0 )}$ & $\mathrm{H}$ & $\mathrm{H}$ & $4-\mathrm{OH}-\mathrm{PhC}_{2} \mathrm{H}_{4}-$ & $\mathrm{HO}-\mathrm{CH} 2-\mathrm{CH}(\mathrm{OH})-$ \\
Lyngbyastatin 6 & $\mathbf{( 6 1 )}$ & $\mathrm{H}$ & $\mathrm{Me}$ & $4-\mathrm{OH}-\mathrm{PhC}_{2} \mathrm{H}_{4-}$ & $\mathrm{NaO}_{3} \mathrm{SO}_{-}-\mathrm{CH}_{2}-\mathrm{CH}(\mathrm{OH})-$ \\
Lyngbyastatin 8 & $\mathbf{( 6 2 )}$ & $\mathrm{H}$ & $\mathrm{H}$ & $i-\mathrm{Pr}$ & $\mathrm{Me}$ \\
Lyngbyastatin 9 & $\mathbf{( 6 3 )}$ & $\mathrm{H}$ & $\mathrm{H}$ & $i-\mathrm{Pr}$ & $\mathrm{Pr}$ \\
Lyngbyastatin 10 & $\mathbf{( 6 4 )}$ & $\mathrm{Br}$ & $\mathrm{H}$ & $i-\mathrm{Pr}$ & $\mathrm{Pr}$
\end{tabular}

Several additional members of the Ahp (3-amino-6-hyroxy-piperidone) or Amp (3-amino-6methoxy-piperidone) containing class of depsipeptides have been isolated and characterized from various species of Lyngbya. Lyngbyastatins 4-6 (59-61), were isolated from the marine cyanobacterium, Lyngbya confervoides which was collected off the Florida Atlantic coast $[44,45]$. Lyngbyastatins 8-10 (62-64) were isolated from the marine cyanobacterium Lyngbya semiplena, which was collected in Tumon Bay, Guam [46]. A Lyngbya sp., which was collected from a mangrove 
channel at Summerland Key in Florida, provided lyngbyastatin 7 (65) [45], somamide B (66) [47] and kempopeptins A and B (67-68) [48]. This class of compounds inhibits serine proteases, although the group exhibits a wide range of potency and varied selectivity (Table 1). When compared to the inhibitory activity of tiglicamides A-C (44-46), the Ahp containing depsipeptides are two to three orders of magnitudes more effective against porcine pancreatic elastase in vitro (Table 1). Like the tiglicamides (44-46) and the largamides (47-49), the Ahp containing serine proteases retain selectivity for elastase over chymostrysin or trypsin. Extensive structure activity studies as well as the crystal structures of the related desipeptide scyptolin A (69) bound to elastase [49,50] and cyanopeptolin A90720A bound to trypsin [51], revealed important interactions in the enzyme binding site and provided critical insights into the selectivity of this class of inhibitors. In the co-crystal structure of scyptolin-elastase, the threonine residue that forms ester bond occupies the S2 subsite of the protease. The valine which is $\mathrm{C}$-terminal to this threonine binds the $\mathrm{S} 1$ subsite of the protease. The threonine and alanine of the pendant side-chain, bind subunits S3 and S4. The relative potencies of these new depsipeptides are consistent with earlier studies. Hydrophobic residues between the Thr that forms the ester bond of the depsipeptide and the Ahp residue impart selectivity for elastase as exemplified by the lynbyastatins (Abu), kempopeptin A (leucine) and scyptolin A (valine), whereas a basic residue at this position imparts selectivity for trypsin exemplified by kempopeptin B (lysine in 68) and pompanopeptin A (argenine in 55). In comparison with lynbyastatin 7 (65), lyngbyastatins 8-10 (62-64) exhibited weaker inhibition against porcine pancreatic elastase. Lyngbyastatins 8-10 (62-64) and lynbyastatin 7 (65) share the same depsipeptide core. Therefore, the reduced potency may be attributed to differences in the side chain residues. The exclusively hydrophobic residues in the pendant chain may form more favorable electrostatic interactions and hydrogen bonding with the enzyme. The fact that the protease-inhibitory activity is retained in the $O$-methylated (Amp) derivative, lyngbyastatin $6(\mathbf{6 0})$, demonstrates that the hydroxyl group in the Ahp unit is not critical for the inhibition of elastase or chymotrypsin.<smiles>[R]CCCC(=O)N[C@@H](CCC(N)=O)C(=O)N[C@H](C)[C@H](OC(=O)[C@H](NC(=O)[C@H](Cc1ccc(O)cc1)N(C)C)C(C)C)C(=O)N/C(=C\C)C(=O)N[C@H](Cc1ccccc1)C(=O)N1C[C@H](O)CC[C@H]1O</smiles>

Lyngbyastatin 7 (65) $\mathrm{R}=\mathrm{Et}$

Somamide B (66) $\mathrm{R}=\mathrm{H}$

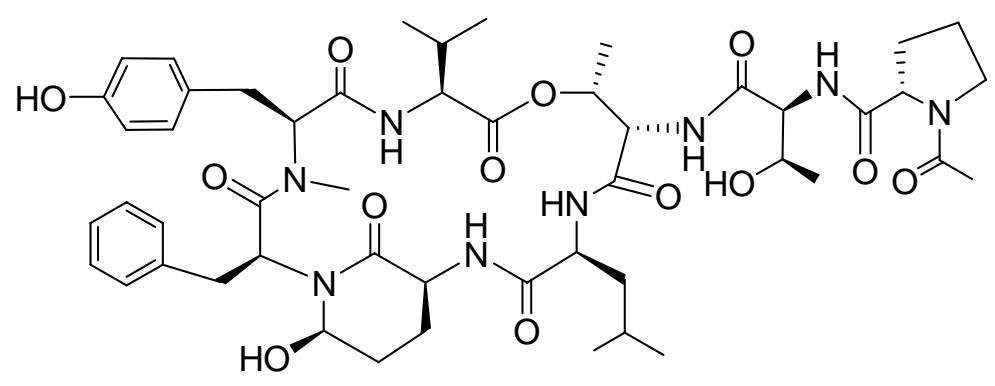




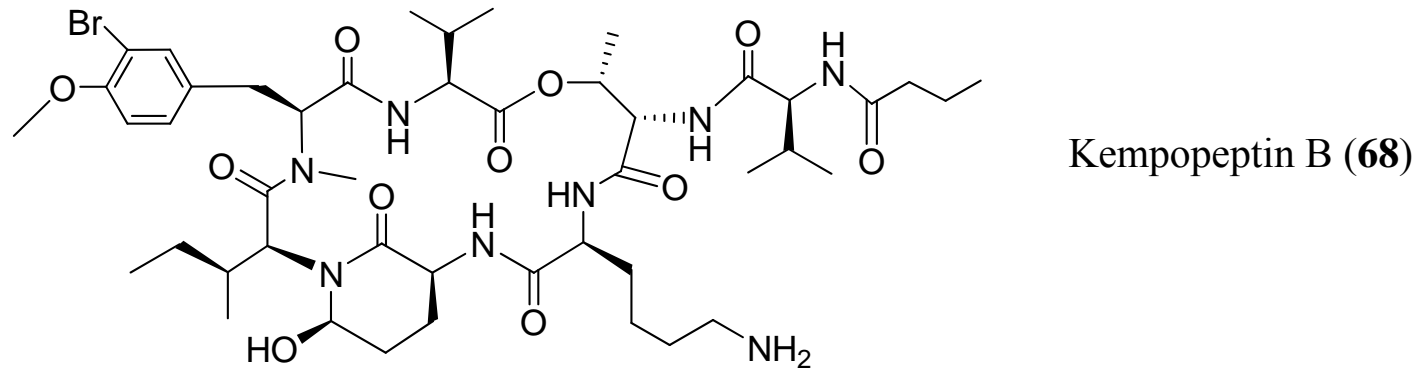

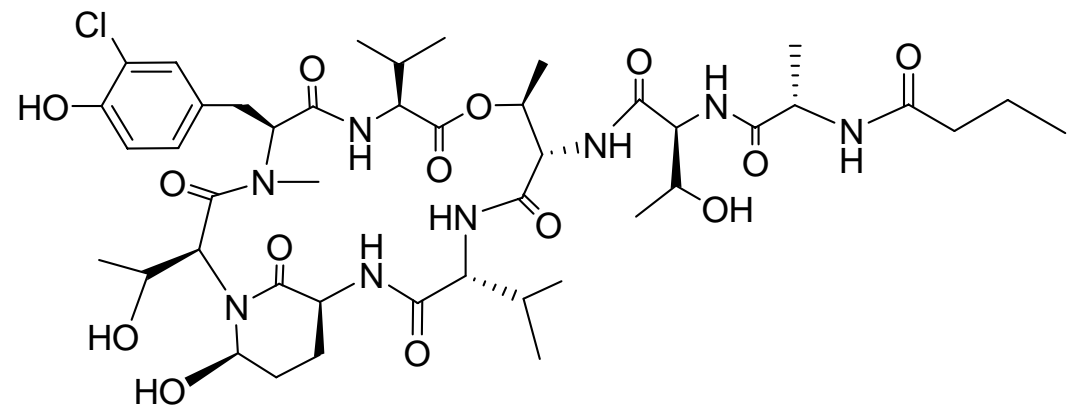

Scyptolin A (69)



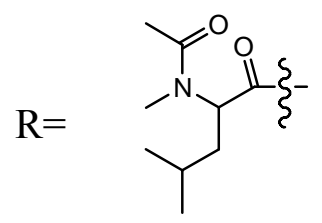

Pahayokolide B (71) $\mathrm{R}=\mathrm{H}$

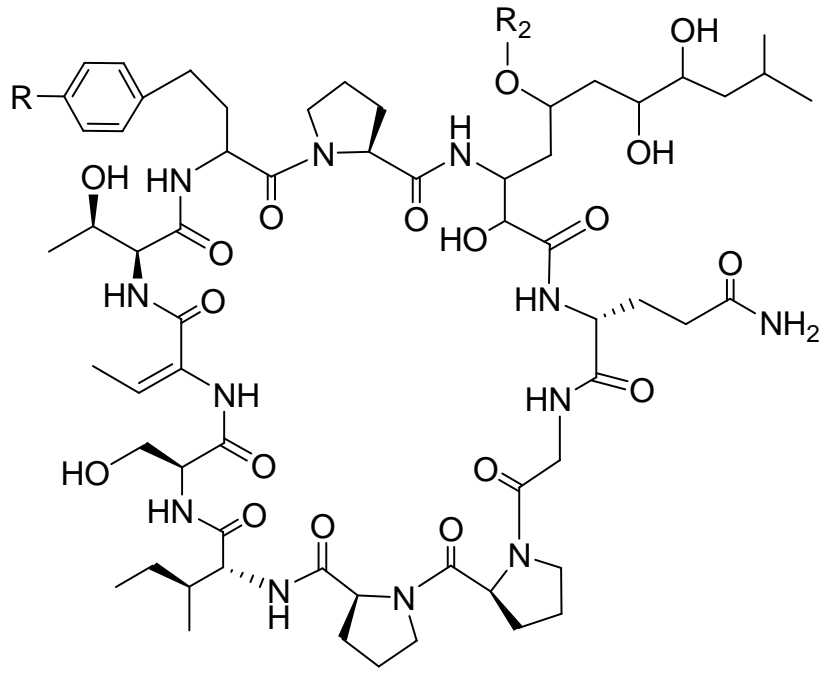

Name

Lyngbyazothrin A (72) Lyngbyazothrin B (73) Lyngbyazothrin C (74) Lyngbyazothrin D (75)<smiles>CC(=O)N(C)[C@@H](Cc1ccc(O)cc1)C(=O)O</smiles>

$\mathrm{C}_{12} \mathrm{H}_{14} \mathrm{NO}_{3}=$ $\mathbf{R}_{\mathbf{2}}$ OMe $\mathrm{H}$ $\mathrm{H}$ $\mathrm{H}$ OMe $\quad \mathrm{C}_{12} \mathrm{H}_{14} \mathrm{NO}_{3}$ $\mathrm{H} \quad \mathrm{C}_{12} \mathrm{H}_{14} \mathrm{NO}_{3}$ 
Pahayokolides A-B (70-71), lyngbyazothrins A-D (72-75) and schizotrin A (76) are remarkably similar in structure. Pahayokolides A-B (70-71) and lyngbyazothrins A-D (72-75) were produced by a freshwater Lyngbya sp. isolated from the Florida Everglades and the cultured Lyngbya sp. 36.91 SAG collected from Göttingen, Germany respectively [52-54]. On the other hand schizotrin A (76) and the tychonamides (77-78) were isolated from Schizotrix sp. [55] and Tchyonema sp. [56] respectively. Each of these cyclic undecapeptides contains the sequence (Val/Ile/Dhb)-Ser-Dhb(Ser/Thr)-(homo-Phe/homo-Tyr)-Pro-X-Gln-Gly-Pro-(Pro/Phe), where $\mathrm{X}$ is an unusual, long-chain $\alpha, \gamma$-hydroxy- $\beta$ - amino acid. In the pahayokolides (70-71), the lyngbyazothrins (72-75) and schizotrin A (76) the $\alpha, \gamma$-hydroxy- $\beta$-amino acid is 3 -amino-2,5,7,8-tetrahydroxy-10-methylundecanoic acid (Athmu) and in tychonamides (77-78) it is a 3-amino-2,5,7,-trihydroxy-8-phenyloctanoic acid moiety (Atpoa). The $\gamma$-hydroxy group may or may not be decorated through an ester linkage to an $\mathrm{N}$-acetyl- $\mathrm{N}$ methyl leucine (pahayokolides and tychonamides) an $N$-butyroyl- $N$-methyl alanine (schizotrin A) or an $\mathrm{N}$-acetyl- $N$-methyl tyrosine (lyngbyazothrins). To the best of our knowledge, these two long-chain $\alpha, \gamma$-hydroxy- $\beta$-amino acids have not been observed elsewhere. It may be noteworthy that the pahayokolides, schizotrin, the lynbyazothrins and tychonamides, which are remarkably similar in structure, were all isolated from freshwater species. Pahayokolide A (70) inhibits a number of cancer cell lines over a range of concentrations ( $\mathrm{IC}_{50}$ varied from 2.13 to $44.57 \mu \mathrm{M}$ ), is acutely toxic to zebrafish embryos $\left(\mathrm{LC}_{50}=2.15 \mu \mathrm{M}\right)$, and only marginally toxic against brine shrimp at the highest concentrations tested $(1 \mathrm{mg} / \mathrm{mL})$ [57]. The mixture of lyngbyazothrins A (72) and B (73) showed only low antimicrobial activity against Micrococcus flavus, whereas the mixture of lyngbyazothrins $\mathrm{C}$ (74) and D (75) was active against Bacillus subtilis, Escherichia coli, Pseudomonas aeruginosa, and Serratia marcescens. It seems that the acyl residue at C-5 of Athmu plays an important role in antimicrobial activity. This assumption was supported by the activity and structure of pahayokolides A-B (70-71).

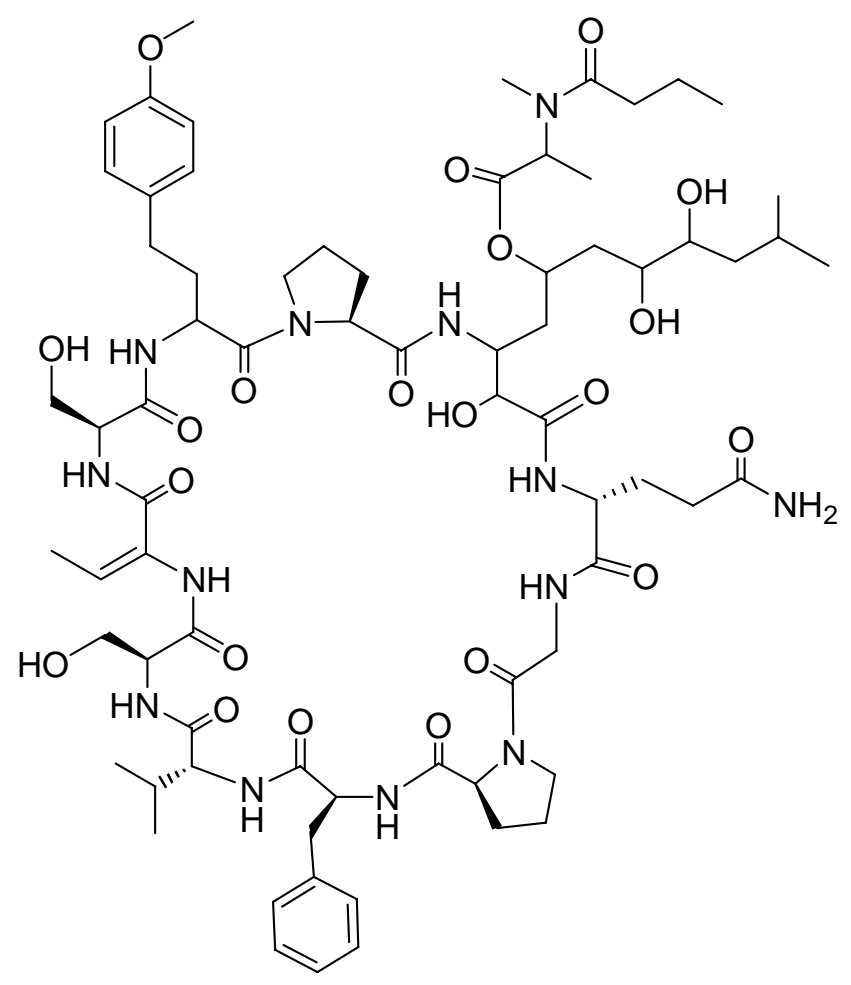




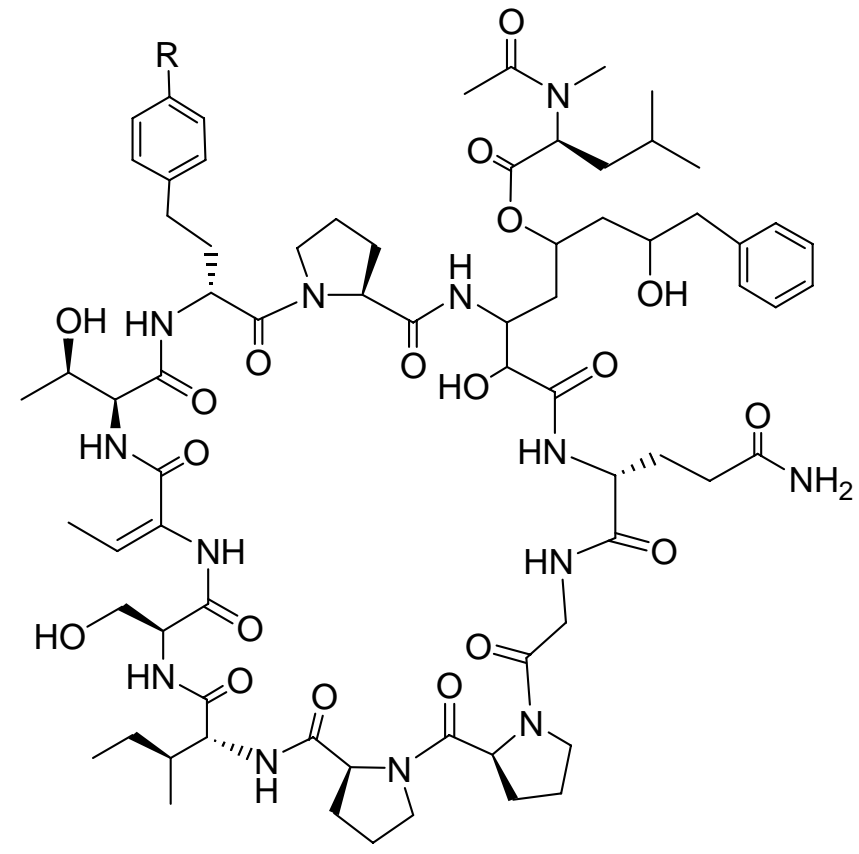

Tychonamide A (77) $\mathrm{R}=\mathrm{CH}_{3} \mathrm{O}$

Tychonamide B (78) $\mathrm{R}=\mathrm{H}$

Fifty new peptides isolated from Lyngbya species, reported since 2006 have been reviewed and their bioactivities discussed. All but six of these new compounds were derived from marine species of Lyngbya, although it is likely that this represents a sampling bias rather than a significant difference in biosynthetic capability between marine and freshwater species. The genus Lyngbya appears to be an emerging source of bioactive peptides. A search of Chemical Abstracts for original research articles using the keywords "Lyngbya" and "peptide" returns 105 citations from 1980 to the present, of which nearly $1 / 3$ have been published during the time covered by this review. In a recent review, Welker described seven major and three minor structural classes which encompass just over $50 \%$ of all known cyanaobacterial peptides [12]. In contrast, only 11 of the 50 new peptides covered in this review fall within one of the identified classes: pompanopeptin A (55), lyngbyastatins 4-10 (59-64) and kempopeptins A and B (67-68) belong to the larger group of cyanopeptolins. While pompanopeptin B (56) falls within the anabaenopeptins. Lyngbya derived peptides share many features with other cyanobacterial peptides, such as N-methylation, the incorporation of D-amino acids, thiazolines or oxazolines and subunits of polyketide or mixed-polyketide and non-ribosomal peptide origin. Nonetheless, the majority of the peptides covered is unique to Lyngbya species and encompass one or only a few analogs. It is common for cyanobacteria, to produce more than one member of a certain structural class. This phenomenon is partially a result of relaxed specificity of biosynthetic enzymes [58]. As prokaryotic polyketide synthases (PKS) can show considerable substrate tolerance [59], so may adenylation domains of non-ribosomal peptide synthetase (NRPS) accept different amino acids within a group of polar or nonpolar residues [60]. Natural structural diversification may also be the result of slight genetic variation or a slightly changed environment. With the possible exception of the linear dragonamides and almiramides, it is likely that these peptides are made non-ribosomally. To date, five biosynthetic pathways for Lyngbya peptides have been identified; barbamide, curacin A, lyngbyatoxin, jamacamide, and hectochlorin [61-65]. These pathways serve to illustrate the tremendous biosynthetic diversity offered by this genus. 
A number of the reviewed Lyngbya peptides, especially acyclic peptides (8-12 and 17) and cyclic peptides without branches (25-26, 28-30, 32, 35, 39, 53-54) exhibit cytotoxic activity against the various cancer cell lines. Only one cyclic Lyngbya peptide with branches, pahayokolide A inhibits a number of cancer cell lines over a range of concentrations. However, most of the reviewed cyclic branched-peptides $(\mathbf{4 4 - 4 9}, \mathbf{5 5}, \mathbf{5 9 - 6 5}, \mathbf{6 7 - 6 8})$ inhibit proteases with a wide range of potency and varied selectivity. Bioactive Lyngbya peptides may be considered to be a valuable pool of lead compounds in structure-based drug design and discovery.

\section{Acknowledgements}

L. L. is grateful to the FIU Graduate School for a dissertation year fellowship.

\section{References and Notes}

1. Stanley, S.M. Earth System History, 2nd ed.; WH Freeman \& Co.: New York, NY, USA, 2004; p. 263.

2. Tan, L.T. Bioactive natural products from marine cyanobacteria for drug discovery. Phytochemistry 2007, 68, 954-979.

3. Gerwick, W.H.; Roberts, M.A.; Proteau, P.J.; Chen, J.L. Screening cultured marine microalgae for anticancer-type activity. J. Appl. Phycol. 1994, 6, 143-149.

4. Gerwick, W.H.; Tan, L.T.; Siachitta, N. Nitrogen-containing metabolites from marine cyanobacteria. In The Alkaloids; Academic Press: San Diego, CA, USA, 2001; pp. 75-184.

5. Namikoshi, M.; Rinehart, K.L. Bioactive compounds produced by cyanobacteria. J. Ind. Microbial. Biotechnol. 1996, 17, 373-384.

6. Mayer, M.S.; Gustafson, K.R. Antitumor and cytotoxic compounds. Int. J. Cancer 2003, 105, 291-299.

7. Trimurtulu, G.; Ohtani, I.; Patterson, G.M.L.; Moore, R.E.; Corbett, T.H.; Valeriote, F.A.; Dechik, L. Total structures of cryptophycins, potent antitumor depsipeptides from the blue-green alga Nostoc sp. strain GSV 224. J. Am. Chem. Soc. 1994, 116, 4729-4737.

8. D’Agostino, G.; del Campo, J.; Mellado, B.; Izquierdo, M.A.; Minarik, T.; Cirri, L.; Marini, L.; Perez-Gracia, J.L.; Scambia, G. A multicenter phase II study of the cryptophycin analog LY355703 in patients with platinum-resistant ovarian cancer. Int. J. Gynecol. Cancer 2006, 16, 71-76.

9. Simmons, T.L.; Andrianasolo, E.; McPhail, K.; Flatt, P.; Gerwick, W.H. Marine natural products as anticancer drugs. Mol. Cancer Ther. 2005, 4, 333-342.

10. Shnyder, S.D.; Cooper, P.A.; Millington, N.J.; Pettit, G.R.; Bibby, M.C. Auristatin PYE, a novel synthetic derivative of dolastatin 10 , is highly effective in human colon tumour models. Int. J. Oncol. 2007, 31, 353-360.

11. Ebbinghaus, S.; Hersh, E.; Cunningham, C.C.; O'Day, S.; McDermott, D.; Stephenson, J.; Richards, D.A.; Eckardt, J.; Haider, O.L.; Hammond, L.A. Phase II study of synthadotin (SYN-D; ILX651) administered daily for 5 consecutive days once every 3 weeks in patients with inoperable locally advanced or metastatic melanoma. In Proceedings of the 2004 American Society of Clinical Oncology Annual Meeting, New Orleans, LA, USA, June 2004; Abstr. \#7530. 
12. Welker, M.; von Döhren, H. Cyanobacterial peptides-Nature's own combinatorial biosynthesis. FEMS Microiol. Rev. 2006, 30, 530-563.

13. Speziale, B.J.; Dyck, L.A. Lyngbya infestations: comparative taxonomy of Lyngbya wollei comb. nov. (Cyanobacteria). J. Phycol. 1992, 28, 693-706.

14. Jiménez, J.I.; Scheuer, P.J. New lipopeptides from the Caribbean cyanobacterium Lyngbya majuscula. J. Nat. Prod. 2001, 64, 200-203.

15. McPhail, K.L.; Correa, J.; Linington, R.G.; Gonzalez, J.; Ortega-Barría, E.; Capson, T.L.; Gerwick, W.H. Antimalarial linear lipopeptides from a Panamanian strain of the marine cyanobacterium Lyngbya majuscula. J. Nat. Prod. 2007, 70, 984-988.

16. Gunasekera, S.P.; Ross, C.; Paul, V.J.; Matthew, S.; Luesch, H. Dragonamides C and D, linear lipopeptides from the marine cyanobacterium brown Lyngbya polychroa. J. Nat. Prod. 2008, 71, 887-890.

17. Balunas, M.J.; Linington, R.G.; Tidgewell, K.; Fenner, A.M.; Ureña, L.D.; Togna, G.D.; Kyle, D.E.; Gerwick, W.H. Dragonamide E, a modified linear lipopeptide from Lyngbya majuscula with antileishmanial activity. J. Nat. Prod. 2010, 73, 60-66.

18. Sanchez, L.M.; Lopez, D.; Vesely, B.A.; Della, Togna G.; Gerwick, W.H.; Kyle, D.E.; Linington, R.G. Almiramides A-C: discovery and development of a new class of leishmaniasis lead compounds. J. Med. Chem. 2010, [Epub ahead of print].

19. Teruya, T.; Sasaki, H.; Fukazawa, H.; Suenaga, K. Bisebromoamide, a potent cytotoxic peptide from the marine cyanobacterium Lyngbya sp.: isolation, stereostructure, and biological activity. Org. Lett. 2009, 11, 5062-5065.

20. Kwan, J. C.; Eksioglu, E.A.; Liu, C.; Paul, V.J.; Luesch, H. Grassystatins A-C from marine cyanobacteria, potent cathepsin $\mathrm{E}$ inhibitors that reduce antigen presentation. J. Med. Chem. 2009, $52,5732-5747$.

21. Soria-Mercado, I.E.; Pereira, A.; Cao, Z.; Murray, T.F.; Gerwick, W.H. Alotamide A, a novel neuropharmacological agent from the marine cyanobacterium Lyngbya bouillonii. Org. Lett. 2009, 11, 4704-4707.

22. Gutiérrez, M.; Suyama, T.L.; Engene, N.; Wingerd, J.S.; Matainaho, T.; Gerwick, W.H. Apratoxin D, a potent cytotoxic cyclodepsipeptide from Papua New Guinea collections of the marine cyanobacteria Lyngbya majuscula and Lyngbya sordida. J. Nat. Prod. 2008, 71, 1099-1103.

23. Simmons, T.L.; Coates, R.C.; Clark, B.R.; Engene, N.; Gonzalez, D.; Esquenazi, E.; Dorrestein, P.C.; Gerwick, W.H. Biosynthetic origin of natural products isolated from marine microorganisminvertebrate assemblages. Proc. Natl. Acad. Sci. USA 2008, 105, 4587-4594.

24. Matthew, S.; Schupp, P.J.; Luesch, H. Apratoxin E, a cytotoxic peptolide from a Guamanian collection of the marine cyanobacterium Lyngbya bouillonii. J. Nat. Prod. 2008, 71, 1113-1116.

25. Tripathi, A.; Puddick, J.; Prinsep, M.R.; Lee, P.P.F.; Tan, L.T. Hantupeptin A, a cytotoxic cyclic depsipeptide from a Singapore collection of Lyngbya majuscula. J. Nat. Prod. 2009, 72, 29-32.

26. Tripathi, A.; Puddick, J.; Prinsep, M.R.; Lee, P.P.F.; Tan, L.T. Hantupeptins B and C, cytotoxic cyclodepsipeptides from the marine cyanobacterium Lyngbya majuscula. Phytochemistry 2009, $72,29-32$. 
27. Bunyajetpong, S.; Yoshida, W.Y.; Sitachitta, N.; Kaya, K. Trungapeptins A-C, cyclodepsipeptides from the marine cyanobacterium Lyngbya majuscula. J. Nat. Prod. 2006, 69, 1539-1542.

28. Taniguchi, M.; Nunnery, J.K.; Engene, N.; Esquenazi, E.; Byrum, T.; Dorrestein, P.C.; Gerwick, W.H. Palmyramide A, a cyclic depsipeptide from a Palmyra Atoll collection of the marine cyanobacterium Lyngbya majuscula. J. Nat. Prod. 2010, 73, 393-398.

29. Tan, L.T.; Sitachitta, N.; Gerwick, W.H. The guineamides, novel cyclic depsipeptides from a Papua New Guinea collection of the marine cyanobacterium Lyngbya majuscula. J. Nat. Prod. 2003, 66, 764-771.

30. Liu, W.T.; Ng, J.; Meluzzi, D.; Bandeira, N.; Gutierrez, M.; Simmons, T.L.; Schultz, A.W.; Linington, R.G.; Moore, B.S.; Gerwick, W.H.; Pevzner, P.A.; Dorrestein, P.C. Interpretation of tandem mass spectra obtained from cyclic nonribosomal peptides. Anal. Chem. 2009, 81, 4200-4209.

31. Malloy, K.; Engene, N.; Pedler, B.; Clark, B.R.; Gerwick, W.H. Isolation, structure elucidation, and SAR perspectives of cyanobacterial cyclic depsipeptides containing the unique Dhoya (3hydroxy-2,2-dimethyl-7-octynoic acid) fragment and its derivatives. In 42nd Western Regional Meeting of the American Chemical Society, Las Vegas, NV, USA, September 2008.

32. Kwan, J.C.; Rocca, J.R.; Abboud, K.A.; Paul, V.J.; Luesch, H. Total structure determination of grassypeptolide, a new marine cytotoxin. Org. Lett. 2008, 10, 789-792.

33. Hawkins, C.J.; Lavin, M.F.; Marshall, K.A.; van den Brenk, A.L; Watters, D.J. Structure-activity relationships of the lissoclinamides: cytotoxic cyclic peptides from the ascidian Lissoclinum patella. J. Med. Chem. 1990, 33, 1634-1638.

34. Wipf, P.; Fritch, P.C.; Geib, S.J.; Sefler, A.M. Conformational studies and structure-activity analysis of lissoclinamide 7 and related cyclopeptide alkaloids. J. Am. Chem. Soc. 1998, 120, 4105-4112.

35. Gunasekera, S.P.; Ritson-Williams, R.; Paul, V.J. Carriebowmide, a new cyclodepsipeptide from the marine cyanobacterium Lyngbya polychroa. J. Nat. Prod. 2008, 71, 2060-2063.

36. Pereira, A.; Cao, Z.; Murray, T.F.; Gerwick, W.H. Hoiamide A, a sodium channel activator of unusual architecture from a consortium of two Pupa New guinea cyanobactiera. Chem. Biol. 2009, 16, 893-906.

37. Simmons, T.L.; Nogle, L.M.; Media, J.; Valeriote, F.A.; Mooberry, S.L.; Gerwick, W.H. Desmethoxymajusculamide $\mathrm{C}$, a cyanobacterial depsipeptide with potent cytotoxicity in both cyclic and ring-opened forms. J. Nat. Prod. 2009, 72, 1011-1016.

38. Matthew, S.; Paul, V.J.; Luesch, H. Tiglicamides A-C, cyclodepsipeptides from the marine cyanobacterium Lyngbya confervoides. Phytochemistry 2009, 70, 2058-2063.

39. Matthew, S.; Paul, V.J.; Luesch, H. Largamides A-C, tiglic acid-containing cyclodepsipeptides with elastase-inhibitory activity from the marine cyanobacterium Lyngbya confervoides. Planta Med. 2009, 75, 528-533.

40. Kleinkauf, H.; Von Döhren, H. A nonribosomal system of peptide biosynthesis. Eur. J. Biochem. 1996, 236, 335-351. 
41. Jiménez, J.I.; Vansach, T.; Yoshida, W.Y.; Sakamoto, B.; Pörzgen, P.; Horgen, F.D. Halogenated fatty acid amides and cyclic depsipeptides from an eastern Caribbean collection of the cyanobacterium Lyngbya majuscula. J. Nat. Prod. 2009, 72, 1573-1578.

42. Matthew, S.; Ross, C.; Paul, V.J.; Luesch, H. Pompanopeptins A and B, new cyclic peptides from the marine cyanobacterium Lyngbya confervoides. Tetrahedron 2008, 64, 4081-4089.

43. Murakami, M.; Suzuki, S.; Itou, Y.; Kodani, S.; Ishida, K. New anabaenopeptins, potent carboxypeptidase-A inhibitors from the cyanobacterium Aphanizomenon flos-aquae. J. Nat. Prod. 2000, 63, 1280-1282.

44. Matthew, S.; Ross, C.; Rocca, J.R.; Paul, V.J.; Luesch, H. Lyngbyastatin 4, a dolastatin 13 analog with elastase and chymotrypsin inhibitory activity from the marine cyanobacterium Lyngbya confervoides. J. Nat. Prod. 2007, 70, 124-127.

45. Taori, K.; Matthew, S.; Rocca, J.R.; Paul, V.J.; Luesch, H. Lyngbyastatins 5-7, potent elastase inhibitors from Floridian marine cyanobacteria, Lyngbya spp. J. Nat. Prod. 2007, 70, 1593-1600.

46. Kwan, J.C.; Taori, K.; Paul, V.J.; Luesch, H. Lyngbyastatins 8-10, elastase inhibitors with cyclic depsipeptide scaffolds isolated from the marine cyanobacterium Lyngbya semiplena. Mar. Drugs 2009, 7, 528-538.

47. Nogle, L.M.; Williamson, R.T.; Gerwick, W.H. Somamides A and B, two new depsipeptide analogs of dolastatin 13 from a Fijian cyanobacterial assemblage of Lyngbya majuscula and Schizothrix species. J. Nat. Prod. 2001, 64, 716-719.

48. Taori, K.; Paul, V.J.; Luesch, H. Kempopeptins A and B, serine protease inhibitors with different selectivity profiles from a marine cyanobacterium, Lyngbya sp. J. Nat. Prod. 2008, 71, 1625-1629.

49. Matern, U.; Schleberger, C.; Jelakovic, S.; Weckesser, J.; Schulz, E.G. Binding structure of elastase inhibitor scyptolin A. Chem. Biol. 2003, 10, 997-1001.

50. Matern, U.; Oberer, L.; Falchetto, R.A.; Erhard, M.; König, W.A.; Herdman, M.; Weckesser, J. Scyptolin A and B, cyclic depsipeptides from axenic cultures of Scytonema hofmanni PCC 7110. Phytochemistry 2001, 58, 1087-1095.

51. Lee, A.Y.; Smitka, T.A.; Bonjouklian, R.; Clardy, J. Atomic structure of the trypsin-A90720A complex: a unified approach to structure and function. Chem. Biol. 1994, 1, 113-117.

52. An, T.; Krishnaswamy, T.; Kumar, S.; Wang, M.; Liu, L.; Lay, J., Jr.; Liyanage, R.; Berry, J.; Gantar, M.; Marks, V.; Gawley, R.E.; Rein, K.S. Structures of pahayokolides A and B, two cyclic peptides from a Lyngbya sp. J. Nat. Prod. 2007, 70, 730-735.

53. Zainuddin, N.E.; Jansen, R.; Nimtz, M.; Wray, V.; Preisitsch, M.; Lalk, M.; Mundt, S. Lyngbyazothrins A-D, antimicrobial cyclic undecapeptides from the cultured cyanobacterium Lyngbya sp. J. Nat. Prod. 2009, 72, 1373-1378.

54. Zainuddin, N.E.; Jansen, R.; Nimtz, M.; Wray, V.; Preisitsch, M.; Lalk, M.; Mundt, S. Corrigendum to: Lyngbyazothrins A-D, antimicrobial cyclic undecapeptides from the cultured cyanobacterium Lyngbya sp. J. Nat. Prod. 2009, 72, 2080. The correct absolute configuration of the Gln residue is $R$ as showed in the discussion.

55. Pergament, I.; Carmeli, S. Schizotrin A, a novel antimicrobial cyclic peptide from a cyanobacterium. Tetrahedron Lett. 1994, 35, 8473-8476. 
56. Mehner, C.; Mueller, D.; Krick, A.; Kehraus, S.; Löeser, R.; Güetschow, M.; Maier, A.; Fiebig, H.F.; Brun, R.; Köenig, G.M. A novel $\beta$-amino acid in cytotoxic peptides from the cyanobacterium Tychonema sp. Eur. J. Org. Chem. 2008, 10, 1732-1739.

57. Berry, J.P.; Gantar, M.; Gawley, R.E.; Wang, M.; Rein, K.S. Pharmacology and toxicology of pahayokolide A, a bioactive metabolite from a freshwater species of Lyngbya isolated from the Florida Everglades. Comp. Biochem. Physiol., Part C: Toxicol. Pharmacol. 2004, 139, 231-238.

58. Magarvey, N.A.; Beck, Z.Q.; Golakoti, T.; Ding, Y.; Huber, U.; Hemscheidt, T.K.; Abelson, D.; Moore, R.E.; Sherman, D.H. Biosynthetic characterization and chemoenzymatic assembly of the cryptophycins. Potent anticancer agents from cyanobionts. ACS Chem. Biol. 2006, 1, 766-779.

59. Watts, R.E.; Tse, M.L.; Khosla, C. Substrate tolerance of module 6 of the epothilone synthetase. Biochemistry 2007, 46, 3385-3393.

60. Challis, G.L.; Ravel, J.; Townsend, C.A. Predictive, structure-based model of amino acid recognition by nonribosomal peptide synthetase adenylation domains. Chem. Biol. 2000, 7, 211-224.

61. Chang, Z.; Flatt, P.; Gerwick, W.H.; Nguyen, V.A.; Willis, C.L.; Sherman, D.H. The barbamide biosynthetic gene cluster: a novel marine cyanobacterial system of mixed polyketide synthase (PKS)-non-ribosomal peptide synthetase (NRPS) origin involving an unusual trichloroleucyl starter unit. Gene 2002, 296, 235-247.

62. Chang, Z.; Sitachitta, N.; Rossi, J.V.; Roberts, M.A.; Flatt, P.M.; Jia, J.; Sherman, D.H.; Gerwick, W.H. Biosynthetic pathway and gene cluster analysis of curacin A, an antitubulin natural product from the tropical marine cyanobacterium Lyngbya majuscula. J. Nat. Prod. 2004, 67, 1356-1367.

63. Edwards, D.J.; Gerwick, W.H. Lyngbyatoxin biosynthesis: sequence of biosynthetic gene cluster and identification of a novel aromatic prenyltransferase. J. Am. Chem. Soc. 2004, 126, 11432-11433.

64. Edwards, D.J.; Marquez, B.L.; Nogle, L.M.; McPhail, K.; Goeger, D.E.; Roberts, M.A.; Gerwick, W.H. Structure and biosynthesis of the jamaicamides, new mixed polyketide-peptide neurotoxins from the marine cyanobacterium Lyngbya majuscula. Chem. Biol. 2004, 11, 817-833.

65. Ramaswamy, A.V.; Sorrels, C.M.; Gerwick, W.H. Cloning and biochemical characterization of the hectochlorin biosynthetic gene cluster from the marine cyanobacterium Lyngbya majuscula. J. Nat. Prod. 2007, 70, 1977-1986.

(C) 2010 by the authors; licensee MDPI, Basel, Switzerland. This article is an Open Access article distributed under the terms and conditions of the Creative Commons Attribution license (http://creativecommons.org/licenses/by/3.0/). 